\title{
Assessment of damage of Endodontic Instruments with Naked Eye and Optical Instruments
}

\section{Procjena oštećenja endodontskih instrumenata vizualno $i$ optičkim pomagalima}

\author{
1 Private Dental Office, Zagreb, Croatia \\ Privatna ordinacija dentalne medicine, Zagreb, Hrvatska \\ 2 Department of Endodontics and Restorative Dentistry, School of Dental Medicine, University of Zagreb, Croatia \\ Zavod za restaurativnu stomatologiju i endodonciju Stomatološkog fakulteta Sveučilišta u Zagrebu
}

Abstract

Objectives: To determine the accuracy of visual damage evaluation of rotating and reciprocal endodontic instruments with the naked eye and optical devices. Material and methods: Four examiners were involved, divided into two age groups: I. 20-30 years, $n=2$, II. $40-50$ years, $n=2$. They visually assessed the existence of damage to rotating or reciprocal endodontic instruments by their naked eye and with two types of optical aids. A total of 239 instruments from different manufacturers were evaluated by each examiner. Before damage estimation, each examiner calibrated the eye on a new instrument. Sensitivity of the detection method was calculated as by the naked eye. When an instrument was detected as damaged by the naked eye, the damage assessment was stopped and the instrument was considered to be damaged by the other two methods, as well. Results: Damage was found in 178 instruments. Sensitivity of the naked eye was calculated to be $49.7 \%$, for the loupe $66.2 \%$ and for the operating microscope $76.5 \%$. The three methods of damage assessment had significant differences $(p<0.05)$ in sensitivity. Conclusion: It was concluded that there is a significant difference between age groups in estimating instrument damage. Also, it was noted that the damage assessment with the naked eye and optical aids were different. Finally, in terms of ease of damage recognition, significant differences between the types of engine-driven endodontic instruments were found. However, no type of instrument was more prone to damage than any other type of instrument.
Received: December 27, 2020

Accepted: March 18, 2021

Address for correspondence Ivan Šalinović

University of Zagreb

School of Dental Medicine

Department of Endodontics and

Restorative Dentistry

Gundulićeva 5, 10000 Zagreb, Croatia

Phone: +38514802126

isalinovic@sfzg.hr

MeSH terms: Equipment Failure Author keywords: Dental Instruments; Damage Assessment

\section{Introduction}

Endodontics is a branch of dental medicine that deals with the pathological processes of dental pulp and their consequences on the tooth and surrounding tissues. It is considered to be the only area of dentistry that is performed without a clear field of view (1). When performing endodontic procedures, the operator relies heavily on endodontic instruments made of various metal alloys. The advancements in material technology and operating techniques have enabled the use of nickel titanium (Ni-Ti) instruments driven by a machine powered by an external energy source (2). Rotary endodontic instruments were described as very flexible and with better cutting ability, when compared to manual instruments (3) However, Ni-Ti engine-driven instruments, as well as all endodontic instruments irrespective of material, are subject to fatigue, which occurs with repeated loading, thus creating micro cracks (4). Specifically, when used in curved root canals, the instruments are subjected to pressure and a tensile load that is localized at the point of curvature in the canal (5). On the other hand, in straight canals torsional failure occurs at the very top of the instrument while it is still ro-
Uvod

Endodoncija je grana dentalne medicine koja se bavi patološkim procesima zubne pulpe i njihovim posljedicama na zub i okolna tkiva. Smatra se jedinim područjem stomatologije koje se gotovo u cijelosti obavlja bez jasnoga vidnog polja (1). Tijekom endodontskih zahvata terapeut se u velikoj mjeri oslanja na endodontske instrumente izrađene od različitih metalnih legura. Napredak u tehnologiji materijala i operacijskim tehnikama omogućio je upotrebu nikal-titanijevih (NiTi) instrumenata koje pokreće stroj koji se napaja iz vanjskog izvora energije (2). Rotacijski endodontski instrumenti opisani su kao vrlo fleksibilni i s boljim svojstvom rezanja u usporedbi s ručnim instrumentima (3). No, kao i svi endodontski instrumenti, neovisno o materijalu, Ni-Ti instrumenti s motorom podložni su zamoru pa se zbog ponavljanja opterećenja stvaraju mikropukotine (4). Konkretno, kada se upotrebljavaju u zakrivljenim korijenskim kanalima, instrumenti su podvrgnuti tlaku i vlačnom opterećenju koje je lokalizirano na mjestu zakrivljenosti u kanalu (5). S druge strane, u ravnim se kanalima torzijsko oštećenje pojavljuje na samom vrhu rotirajućeg instrumenta (6). Puknuće instrumenta raz- 
tating (6). Instrument fracture is a relatively common complication in endodontic procedures. The removal of a broken instrument is extremely demanding, which makes the favorable outcome of endodontic treatment harder to achieve (7). The complication of a separated instrument in a root canal often occurs due to damaged instruments; therefore, it is important to visually inspect the instrument during the shaping procedure of multirooted teeth with complicated endodontic space anatomy. Engine-driven endodontic instruments are small and the microcracks due to fatigue are even smaller. Naturally, the question arises whether the clinician is able to see such a small damage and react in time to prevent the unwanted instrument separation.

The working fields where dental procedures are performed are relatively small and at different focal lengths, hence few optical aids have gained widespread acceptance in clinical practice $(8,9)$. Apart from better visualization of the working field, the optical aids can be used for better inspection of the surface of the endodontic instrument and possibly detect its damage that cannot be seen with the naked eye. Another factor that has shown to significantly influence the operator's ability to visualize objects in the working field is their eyesight, which is known to deteriorate over time (10).

The aim of this study was to evaluate the accuracy of visual damage assessment of different rotating and reciprocal endodontic instruments with the naked eye and when using optical devices.

The null hypotheses are:

1. There is no difference between the age groups in estimating the $\mathrm{Ni}$-Ti endodontic instruments damage.

2. There is no significant difference in damage assessment when using the naked eye or optical aids.

3. Damage to instruments is equally easy to detect regardless of the type of engine-driven endodontic instrument.

\section{Material and methods}

\section{Examined instruments}

The study was conducted at the School of Dental Medicine, University of Zagreb and approved by its Ethics Committee (approval number 05-PA-30-XXII-12/20). The study involved four dentists divided into two age groups:

I. 20-30 years, $n=2$,

II. $40-50$ years, $n=2$

Each dentist visually assessed the existence of damage to rotating or reciprocal endodontic instruments used in shaping root canals of multirooted teeth. A total of 239 instruments from different manufacturers were estimated by each examiner. The types of instruments evaluated were: Reciproc (VDW Dental, Munich, Germany $n=126$ ), ProTaper Universal (Dentsply Sirona, York, Pennsylvania, USA, $n=$ 59), ProFile (Dentsply Sirona, York, Pennsylvania, USA, $n$ $=15$ ), One curve (Micro mega, Besancon, France, $n=13$ ), ProTaper Next (Dentsply Sirona, York, Pennsylvania, USA, $n=12$ ), ProTaper gold (Dentsply Sirona, York, Pennsylvania, USA, $n=2$ ), HERO shaper (Micro mega, Besancon, France, $n=6$ ), F360 (Komet Dental, Lemgo, Germany, $n=$ 6). The number of times each file had been used was not re- mjerno je česta komplikacija u endodontskim postupcima. Njegovo uklanjanje iznimno je zahtjevno, što otežava postizanje povoljnog ishoda endodontskog liječenja (7). Puknuće u korijenskom kanalu često se događa zbog oštećenih instrumenata i zato je važno vizualno pregledati svaki instrument tijekom postupka instrumentacije kanala sa složenom anatomijom endodontskog prostora. Strojni su endodontski instrumenti mali, a mikropukotine zbog zamora još su manje. Naravno, postavlja se pitanje je li kliničar u stanju vidjeti tako mala oštećenja i reagirati na vrijeme kako bi spriječio neželjeno puknuće instrumenata.

Područja rada stomatoloških zahvata razmjerno su mala i imaju različite žarišne duljine i zato je malo optičkih pomagala široko prihvaćeno u kliničkoj praksi $(8,9)$. Uz bolju vizualizaciju radnog polja, optička pomagala mogu se koristiti za bolji pregled površine endodontskog instrumenta i eventualno otkrivanje njegovih oštećenja koja se ne mogu vidjeti okom. Još jedan čimbenik značajno utječe na sposobnost operatera da vizualizira predmete u radnom polju - to je vid za koji se zna da se $s$ vremenom pogoršava (10).

Cilj ovog istraživanja bio je odrediti točnost procjene oštećenja različitih rotacijskih i recipročnih endodontskih instrumenata samo okom is pomoću optičkih pomagala.

Nulte hipoteze su:

1. ne postoji razlika između dobnih skupina u procjeni oštećenja na nikal-titanijevim endodontskim instrumentima

2. nema značajne razlike u procjeni oštećenja samo okom ili optičkim pomagalima

3. oštećenja je jednako lako otkriti bez obzira na vrstu strojnoga endodontskog instrumenta.

\section{Materijal i metode}

\section{Pregledavani instrumenti}

Istraživanje je provedeno na Stomatološkom fakultetu Sveučilišta u Zagrebu, a odobrilo ga je Etičko povjerenstvo (broj odobrenja 05-PA-30-XXII-12/20). U istraživanju su sudjelovala četiri doktora dentalne medicine podijeljena u dvije dobne skupine:

I. od 20 do 30 godina $-n=2$

II. od 40 do 50 godina $-n=2$.

Svaki je stomatolog vizualno procijenio postoje li oštećenja na rotacijskim ili recipročnim endodontskim instrumentima koji se koriste u oblikovanju korijenskih kanala višekorijenskih zuba. Svaki je pregledao je ukupno 239 instrumenata različitih proizvođača. Vrste ocjenjivanih instrumenata bile su: Reciproc (VDW Dental, München, Njemačka, n = 126), ProTaper Universal (Dentsply Sirona, York, Pennsylvania, SAD, $n=59$ ), ProFile (Dentsply Sirona, York, Pennsylvania, SAD, $n=15$ ), One Curve (Micro mega, Besancon, Francuska, $\mathrm{n}=13$ ), ProTaper Next (Dentsply Sirona, York, Pennsylvania, SAD, $n=12$ ), ProTaper Gold (Dentsply Sirona, York, Pennsylvania, SAD, $\mathrm{n}=2$ ), HERO Shaper (Micro mega, Besancon, Francuska, n = 6), F360 (Komet Dental, Lemgo, 
corded. The examined instruments were discarded by different operators because of a perceived decrease in cutting efficiency; fracture; or any defects observed by the naked eye, such as unwinding, curving or bending. All files were cleaned by an ultrasonic cleaner and sterilized in an autoclave before inspection.

\section{Means of examination}

Before damage estimation, each examiner calibrated the eye on a new instrument. The instruments were first inspected without optical aids, with freedom of choice of the eye-toobject distance, i.e. focal length illuminated by the light from the work unit (KaVo LUX 540 LED, Biberach, Germany). Subsequently, the damaged instruments were selected. Instruments categorized as undamaged by the naked eye were further observed by the Keplerian loupe system (EyeMag Pro $S$, Zeiss, Oberkochen, Germany) at a magnification of $4.3 \times$ and a distance of $400 \mathrm{~mm}$ from the object with illumination from the work unit. The damaged instruments noticed by the loupe system were again indicated as damaged. The instruments that appeared undamaged by the loupe system were further observed under an operating microscope (Zeiss Extaro 300, Oberkochen, Germany), at a magnification of $4 \times$, a distance of $250 \mathrm{~mm}$ and integrated light (Figure 1). Damaged instruments were singled out in the group where the damage was detected under the operating microscope. All examiners were familiar with the use of loupes and microscopes. They were allowed to use their personal corrective glasses to compensate for visual defects while assessing instrument damage. An instrument was considered damaged if at least one examiner detected it using any method. Within the limitations of this study, instruments categorized as undamaged by all examiners and by all optical methods were not included in the statistical analysis. Damage was found in 178 instruments. Sensitivity analysis of various damage detection methods was performed on these samples.

\section{Statistical data analysis}

The sensitivity of each detection method was then evaluated using detection by each of the methods (naked eye, loupe and the microscope) by each individual evaluator as a binary variable: the differences between the variables were then evaluated using the non-parametric McNemar test for related samples, while the differences between instrument and evaluator groups were tested using the non-parametric Mann-Whitney $U$ test for independent samples. The significance level was set at 0.05 and all analyses were made using SPSS software (Release 20.0.0, by IBM SPSS Statistics).
Njemačka, $n=6$ ). Nije zabilježeno koliko je puta pojedini instrument bio upotrijebljen. Ispitivači nisu uzeli u obzir instrumente na kojima su uočili smanjenu učinkovitost rezanja, puknuća, ili bilo koji nedostatak uočen golim okom, poput odmotavanja, zakrivljenosti ili savijanja. Svi su odabrani instrumenti prije inspekcije očišćeni u ultrazvučnoj kupki i sterilizirani u autoklavu.

\section{Način ispitivanja}

Prije procjene oštećenja svaki je ispitivač kalibrirao oko na novom instrumentu. Instrumenti su najprije pregledani bez optičkih pomagala, uz slobodan izbor udaljenosti između oka i predmeta, tj. žarišne duljine, a bili su osvijetljeni svjetlošću radne jedinice (KaVo LUX ${ }^{\mathrm{TM}} 540$ LED, Biberach, Njemačka). Nakon toga odabrani su oštećeni instrumenti. Oni koji su okom kategorizirani kao neoštećeni, dodatno su promatrani sustavom Keplerian lupe (EyeMag Pro S, Zeiss, Oberkochen, Njemačka) u povećanju od 4,3 × i udaljenosti od $400 \mathrm{~mm}$ od objekta, uz osvjetljenje radne jedinice. Instrumenti koji su se pod povećalima pokazali manjkavi ponovno su označeni kao oštećeni, a oni koji su se činili neoštećenima promatrani su operacijskim mikroskopom (Zeiss Extaro 300, Oberkochen, Njemačka) uz povećanje od $4 \times$, udaljenost od $250 \mathrm{~mm}$ i integriranu svjetlost (slika 1.). Oštećeni instrumenti izdvojeni su u skupinu u kojoj je oštećenje otkriveno operacijskim mikroskopom. Svi ispitivači dobro su rukovali povećalima i mikroskopom. Mogli su se koristiti svojim korektivnim naočalama kako bi nadoknadili eventualne nedostatke vida tijekom procjene oštećenja instrumenta. Instrument se smatrao oštećenim ako ga je barem jedan ispitivač tako označio bilo kojom metodom. Unutar ograničenja ove studije instrumenti koje su svi ispitivači kategorizirali kao neoštećene i poslije uporabe svih optičkih metoda, nisu bili uključeni u statističku analizu. Oštećenja su pronađena na 178 instrumenata. Na tim je uzorcima provedena analiza osjetljivosti različitih metoda otkrivanja oštećenja.

\section{Statistička analiza podataka}

Osjetljivost svake metode detekcije procijenjena je kao binarna varijabla nakon što je svaki ispitivač primijenio sve metode (samo okom, povećalom i mikroskopom): razlike između varijabli zatim su procijenjene neparametrijskim McNemarovim testom za zavisne uzorke, a razlike između skupina instrumenata i ispitivača testirane su s pomoću neparametrijskog Mann-Whitneyjeva U-testa za nezavisne uzorke. Razina značajnosti postavljena je na 0,05 i sve su analize učinjene u softveru SPSS (izdanje 20.0.0, IBM SPSS Statistics).

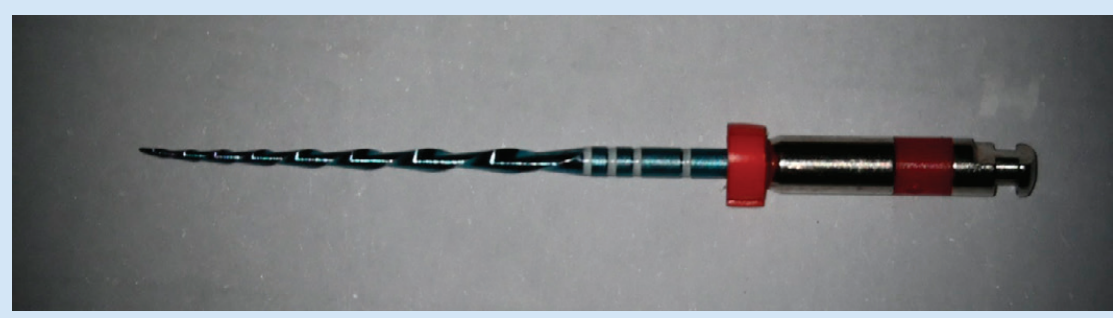

Figure 1 An instrument under a microscope Slika 1. Instrument pod mikroskopom 


\section{Results}

Of the 239 instruments included in the study, 61 $(25.52 \%)$ were excluded from sensitivity of damage assessment method analysis since all four examiners agreed they were undamaged. For the instruments included in the analysis of the assessment method, at least one examiner had to record damage by any one of the three optical methods used in the study: the naked eye, loupe system, and operating microscope. The total number of samples included was 178. Descriptive statistics for the two groups of examiners are given in Table 1.

When calculating the sensitivity of the damage assessment method, we considered that damage visible under the magnifying glass (the loupe) would also be visible by the naked eye. By the same concept, damage visible under the microscope would also be visible under the magnifying glass and by the naked eye. Sensitivity of the naked eye was calculated to be $49,7 \%$, for the loupe $66.2 \%$ and for operat-

\section{Rezultati}

Od 239 instrumenata uključenih u studiju, 61 (25,52\%) isključen je iz analize osjetljivosti metode procjene oštećenja jer su se sva četiri ispitivača složila da nisu oštećeni. Za instrumente uključene u analizu metode procjene barem je jedan ispitivač morao zabilježiti oštećenje bilo kojom od triju optičkih metoda korištenih u istraživanju: samo okom, sustavom povećala i operacijskim mikroskopom. Ukupan broj obuhvaćenih uzoraka bio je 178. Opisni statistički podatci za dvije skupine ispitivača nalaze se u tablici 1 .

Pri izračunavanju osjetljivosti metode procjene oštećenja smatrali smo da će oštećenja vidliiva pod povećalom (lupom) biti vidljiva i okom. Prema istom konceptu, oštećenja vidljiva pod mikroskopom bila bi uočena i pod povećalom i samo okom. Izračunato je da je osjetljivost okom 49,7 \%, za povećalo iznosi $66,2 \%$, a za operacijski mikroskop 76,5 \%. Tri metode procjene štete značajno su se razlikovale $(\mathrm{p}<0,05) \mathrm{u}$ osjetljivosti (tablica 2.).

Table 1 Number and percentages of engine-driven endodontic instruments for which damage was not recorded or was recorded by microscope, loupe or the naked eye. Examiners were divided into two age groups: age group I (20-30 years) and age group II (40-50 years).

Tablica 1. Broj i postoci endodontskih instrumenata na motorni pogon kod kojih oštećenje nije zabilježeno ili je zabilježeno mikroskopom, lupom ili golim okom. Ispitivači su bili podijeljeni u dvije dobne skupine: dobna skupina I (20-30 godina) i dobna skupina II (40-50 godina).

\begin{tabular}{|c|c|c|c|}
\hline & Age group I & Age group II & All examiners \\
\hline Damage not recorded & $73(21 \%)$ & $94(26 \%)$ & $167(23 \%)$ \\
\hline Damage recorded under OM & $29(8 \%)$ & $45(13 \%)$ & $74(10 \%)$ \\
\hline Damage recorded under loupe & $47(13 \%)$ & $70(20 \%)$ & $117(16 \%)$ \\
\hline Damage recorded by naked eye & $207(58 \%)$ & $147(41 \%)$ & $354(50 \%)$ \\
\hline Total & $356(100 \%)$ & $356(100 \%)$ & $712(100 \%)$ \\
\hline
\end{tabular}

Table 2 Sensitivity of methods of damage assessment and confidence intervals for all examiners. The difference between the methods of damage assessment was statistically significant $(p<0.05)$ (McNemar Test).

Tablica 2. Osjetljivost metoda procjene štete i intervali pouzdanosti za sve ispitivače. Razlika između metoda procjene štete bila je statistički značajna ( $p<0,05)$ (McNemar test).

\begin{tabular}{l|c|c}
\multicolumn{1}{c|}{ Method } & \multicolumn{1}{c}{ Sensitivity } & \multicolumn{1}{c}{ CI $\%$} \\
Naked eye $^{1}$ & $49.7 \%$ & $66.1-53.4$ \\
\hline Loupe $^{2}$ & $62.5-69.6$ & $76.5 \%$ \\
\hline Operating microscope & $73.3-79.6$ \\
\hline Invisible & $23.5 \%$ & $20.4-26.7$ \\
\hline Total & $100.0 \%$ &
\end{tabular}

${ }^{1}$ the methods with a different number are significantly different by sensitivity from each other, $\mathrm{p}<0,001, \mathrm{McNemar}$ test for related samples $\bullet \mathrm{xxx}$ $\mathrm{xxx}$

Table 3 Sensitivity of noticing the damage between age groups. The difference between the methods of damage assessment was statistically significant $(p<0.05)$.

Tablica 3. Osjetljivost uočavanja štete između dobnih skupina. Razlika između metoda procjene štete bila je statistički značajna (p <0,05).

\begin{tabular}{c|c|c|c|} 
Method & $\begin{array}{c}\text { Sensitivity } \\
\text { Age group I } \\
\text { Naked eye }\end{array}$ & $58.1 \%$ & $\begin{array}{c}\text { Sensitivity } \\
\text { Age group II }\end{array}$ \\
\hline Loupe & $71.3 \%$ & $41.3 \%$ & $<0.001$ \\
\hline Microscope & $79.5 \%$ & $73.6 \%$ & 0.003 \\
\hline Invisible & $20.5 \%$ & $26.4 \%$ & 0.063 \\
\hline Total & $100.0 \%$ & $100.0 \%$ & 0.063 \\
\hline
\end{tabular}


Table 4 Sensitivity of all optical methods in noticing the damage when comparing conventional wire to M-wire instruments.

Tablica 4. Osjetljivost svih optičkih metoda u uočavanju oštećenja prilikom usporedbe konvencionalne žice s instrumentima s M-žicom.

\begin{tabular}{l|c|c|c|c|c|c|c}
\multicolumn{1}{c}{ Sensitivity } & Conventional & M-wire & C-wire & $\begin{array}{c}\mathbf{p} \\
\text { Conv. vs. } \\
\text { M-wire* }\end{array}$ & $\begin{array}{c}\mathbf{p} \\
\text { Conv. vs. } \\
\text { C-wire* }\end{array}$ & $\begin{array}{c}\mathbf{p} \\
\text { M-wire vs. } \\
\text { C-wire* }\end{array}$ \\
\hline Visible by naked eye & $54.5 \%$ & $45.1 \%$ & $48.1 \%$ & 0.017 & 0.392 & 0.683 \\
\hline Visible under loupe & $71.5 \%$ & $60.4 \%$ & $71.2 \%$ & 0.003 & 0.956 & 0.137 \\
\hline Visible under microscope & $83.0 \%$ & $70.9 \%$ & $76.9 \%$ & 0.003 & 0.295 & 0.366 \\
\hline Invisible & $17.0 \%$ & $29.1 \%$ & $23.1 \%$ & 0.003 & 0.29372 & 0.366 \\
\hline Total & $100.0 \%$ & $100.0 \%$ & $100.0 \%$ & & & &
\end{tabular}

* Mann-Whitney U-test

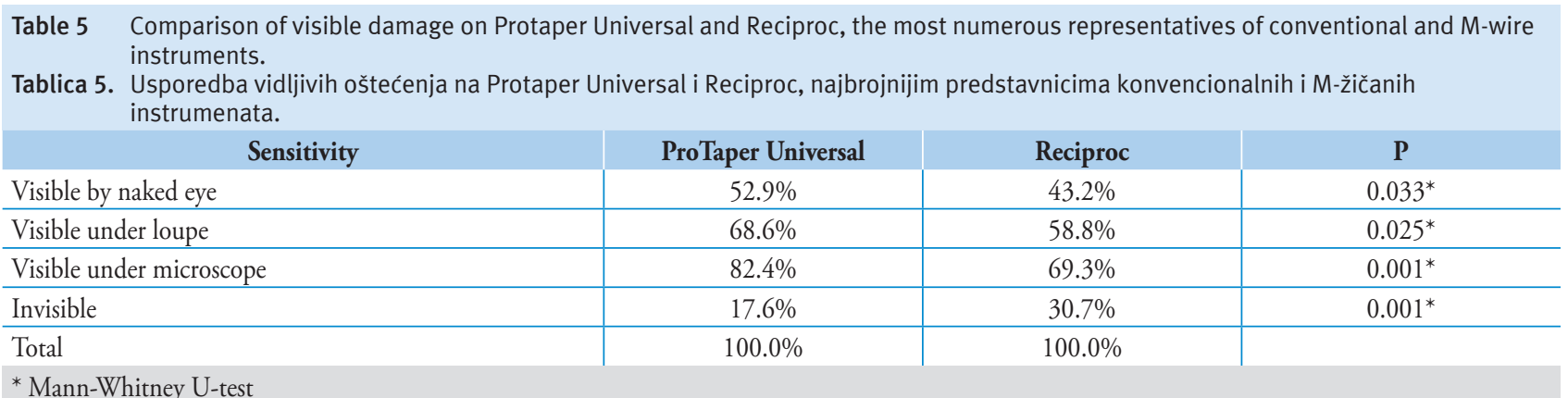

ing microscope $76.5 \%$. The three methods of damage assessment differed significantly $(p<0.05)$ in sensitivity (Table 2$)$.

In order to compare the sensitivity between the younger and older examiners, it was found that the younger examiners were more sensitive to noticing damage by the naked eye and by the loupe (Table 3).

A further analysis of the instruments was divided into groups according to the type of wire, i.e. heat treatment procedures, to which Ni-Ti alloys had been subjected. The conventional wires $(n=72)$, M-wire $(n=91)$ and C-wire $(n=$ 13) were included for further analysis. The gold heat treated group was excluded from further analysis due to a small sample size $(n=2)$.

It was shown that a significantly greater percentage of damage to conventional instruments was visible by any optical method compared to the M-wire instruments (Table 4). Similar results were obtained when ProTaper Universal and Reciproc instruments were compared, as representatives of the two groups. It was again shown that sensitivity to damage assessment was significantly greater in the case of Pro Taper instruments by all methods $(p<0.05)$ (Table 5).

\section{Discussion}

The present study determined the sensitivity of the naked eye, a loupe and an operating microscope in assessing the damage to engine-driven endodontic instruments. Generally, there were three principal advantages of magnifying loupes: compensation for presbyopia, ergonomic and optical benefits (11). A study by Eichenberger et al. (8) found that the visual acuity can be improved by $250-961 \%$ by the use of magnification devices, independent of age and natural visual acuity. This hypothesis was consistent with our experiments. The sensitivity of the microscope was greater compared with
Uspoređivanjem osjetljivosti između mlađih i starijih ispitivača ustanovljeno je da su mlađi osjetljiviji na uočavanje oštećenja samo okom i povećalom (tablica 3.).

Daljnja analiza instrumenata podijeljena je u skupine prema vrsti materijala, tj. prema postupcima toplinske obrade kojima su bile podvrgnute Ni-Ti legure. Konvencionalni instrumenti $(\mathrm{n}=72), \mathrm{M}$-wire $(\mathrm{n}=91)$ i C-wire $(\mathrm{n}=13)$ uključeni su u daljnju analizu. Gold heat skupina izuzeta je iz daljnje analize zbog malog uzorka $(n=2)$.

Dokazano je da je bilo kojim optičkim postupkom vidljiv znatno veći postotak oštećenja na konvencionalnim instrumentima u usporedbi s M-wire instrumentima (tablica 4.). Slični rezultati dobiveni su usporedbom instrumenata ProTaper Universal i Reciproc, kao predstavnika dviju skupina. Ponovno se pokazalo da je osjetljivost procjene oštećenja bila znato veća u slučaju Pro Taper instrumenata i to svim metodama. $(\mathrm{p}<0,05)$ (tablica 5.).

\section{Rasprava}

U ovom istraživanju proučavala se osjetljivost oka, povećala i operacijskog mikroskopa u procjeni oštećenja strojnih endodontskih instrumenata. Općenito su tri glavne prednosti povećala kompenzacija kratkovidnosti te ergonomske i optičke prednosti (11). Istraživanjem Eichenbergera i suradnika (8) utvrđeno je da se oštrina vida može poboljšati za 250 do $961 \%$ upotrebom uređaja za povećanje, neovisno o dobi i prirodnoj oštrini vida. Ta je hipoteza u skladu s našim eksperimentom. Osjetljivost mikroskopa veća je od povećala čak i pri usporedivim čimbenicima povećanja. To se može objasni- 
loupes even at comparable magnification factors. This can be explained by a greater angle between the two optical beams and the static position of the microscope, offsetting any disturbances caused by head movements $(8,12)$.

We focused on the sensitivity of the eye in evaluating any possible damage to endodontic files that had previously been used in endodontic treatment. We have shown that sensitivity of the eye alone is $49.7 \%$, thus showing that the eye alone detects, on average, about half of damage. Therefore, the other half of it remains unrevealed unless optical aids are used. These findings corroborate the study of Stapan (13). It has been observed that fracture of $\mathrm{Ni}$-Ti files can occur with little or no visible evidence of accompanying plastic deformation or, in other words, permanent change of its shape $(14,15)$. Such a situation could possibly lead to repeated use of a damaged instrument, thus increasing the risk of instrument separation when endodontic procedures are performed.

Some examiners had better visual acuity by their naked eye. This could be due to the examiner's age (10). The first group was made of younger assessors. They were able to notice damage by their naked eye with significantly improved astuteness. On the other hand, the older group of examiners benefited more from the use of optical aids. Consequently, the second null-hypothesis has been rejected.

Instrument observation conditions are another important factor. Our experiments were performed during the day and the light from the work unit was used.

As mentioned, the sensitivity of the magnifying glass measurement was $66.2 \%$, while the sensitivity of the microscope measurement was $76.5 \%$. The difference between these methods was statistically significant $(p<0.05)$, between the sensitivity of the measurement of the eye, magnifying glass and microscope. It is questionable whether this is clinically relevant since it is subjective: it depends on the values considered to be "good enough", determined by the level of risk associated with a false negative result. Within the limitations of this study, we have obtained no false positive results.

As far as the type of alloy is concerned, the Ni-Ti alloy was introduced for instrumentation in curved canals, mostly because of their shape memory property associated with temperature changes (16). In addition, they increase the speed of the endodontic procedures, allowing the dentist to invest more time into the irrigation (17). The most visible damages were found on M-wires. The difference was statistically significant $(p<0.05)$ for conventional materials compared to $\mathrm{M}$-wire, while the differences between the $\mathrm{C}$-wire and conventional materials as well as the $\mathrm{C}$-wire and $\mathrm{M}$-wire were not statistically significant. It should be noted that the number of samples for the C-wire was relatively small $(n=52)$, which affects the power of testing, but the values for the Cwire are between those of the $\mathrm{M}$-wire and conventional ones. The difference by each method is statistically significant between the two most commonly used instruments in the experiment, Protaper Universal and Reciproc, which does not mean that one material is more prone to damage than the other. In other words, a higher percentage of damage to the Protaper Universal instruments was optically noticeable compared to Reciproc. ti većim kutom između dviju optičkih zraka i statičnim položajem mikroskopa koji ublažava sve smetnje prouzročene pokretima glave $(8,12)$.

Usredotočili smo se na osjetljivost oka u procjeni eventualnih oštećenja endodontskih instrumenata koji su se već prije upotrebljavali u liječenju. Dokazana je osjetljivost oka od 49,7 \%, dakle, oko u prosjeku otkriva polovinu svih oštećenja. Stoga druga polovina ostaje neotkrivena ako se ne koriste optička pomagala. Ti se podatci podudaraju s nalazima Stapana (13). Uočeno je da se puknuća Ni-Ti instrumenata mogu dogoditi s malo ili nimalo vidljivih dokaza o popratnoj plastičnoj deformaciji ili, drugim riječima, trajnoj promjeni oblika $(14,15)$. Takva bi situacija mogla rezultirati ponovnom upotrebom oštećenog instrumenta, što povećava rizik od puknuća instrumenta kada se obavljaju endodontski postupci.

Neki ispitivači imali su bolju vidnu oštrinu samo okom, što se može objasniti njihovom dobi (10). Naime, prvu skupinu činili su mlađi ocjenjivači. Golim su okom mogli znatno vještije uočiti oštećenja. $S$ druge strane, skupini starijih ispitivača više su koristila optička pomagala. Slijedom toga odbacuje se druga nulta hipoteza.

Uvjeti promatranja instrumenta još su jedan važan čimbenik. Naše istraživanje provedeno je za danjeg svjetla, uz osvjetljenje radne jedinice.

Kao što je istaknuto, osjetljivost mjerenja povećalom bila je $66,2 \%$, a osjetjivost mjerenja mikroskopom $76,5 \%$. Razlika je statistički značajna $(\mathrm{p}<0,05)$ između osjetljivosti mjerenja okom, povećalom i mikroskopom. Klinička važnost toga nalaza je subjektivna i ovisi o tome koje vrijednosti smatramo dovoljno dobrima, a određuje se razinom rizika povezanom s lažno negativnim rezultatom. Unutar ograničenja ove studije nismo pretpostavili lažno pozitivne rezultate.

Kad je riječ o vrstama slitina, legura $\mathrm{Ni}$-Ti koristi se za instrumentaciju u zakrivljenim kanalima, ponajviše zbog svojstva pamćenja oblika povezanog $s$ promjenama temperature (16). Uz to, povećava brzinu endodontskih zahvata te tako omogućuje češće ispiranje (17). Oštećenja su bila najvidljivija na M-žicama. Razlika je bila statistički značajna $(\mathrm{p}<0,05)$ za konvencionalne materijale u usporedbi s M-žicom, a razlike između C-žice i konvencionalnih materijala te C-žice i $\mathrm{M}$-žice nisu bile statistički značajne. Treba imati na umu da je broj uzoraka za C-žicu bio razmjerno malen $(n=52)$, što utječe na snagu ispitivanja, ali vrijednosti za C-žicu su između vrijednosti M-žice i one konvencionalne. Razlika u svakoj metodi statistički je značajna između dvaju najzastupljenijih instrumenata korištenih u eksperimentu - Protaper Universal i Reciproc. Važno je znati da to ne znači da se jedan materijal oštećuje lakšse od drugoga, nego da je optički uočljiv veći postotak oštećenja na instrumentima Protaper Universal u usporedbis Reciprocom.

Osim mnogobrojnih prednosti pri upotrebi operacijskog mikroskopa u endodonciji, uključujući vizualno i ergonomsko poboljš̌nje (18), u sklopu ograničenja ove studije rezultati sugeriraju da je to također najbolje sredstvo za vizualnu procjenu oštećenja instrumenata. To bi moglo smanjiti učestalost pucanja oštećenog instrumenata unutar korijenskog kanala. Ipak, nema dovoljno studija koje se bave tim važnim aspektom endodontske terapije, vjerojatno zato što su se op- 
Apart from the many benefits of using an operating microscope in endodontics, including visual and ergonomic enhancement (18), within the limitations of this study, the results suggest that it is the superior option for therapists to assess an endodontic file for damage. This could reduce the frequency of instrument separation inside the root canal by damaged files. Nonetheless, unexpectedly, there are hardly any studies to address this important aspect of endodontic therapy, possibly due to the relatively recent introduction of optical aids to dentistry (19). Further research is therefore needed.

\section{Conclusion}

It can be concluded that there is a significant difference between age groups in the estimation of instrument damage with younger examiners being superior to notice damage by the naked eye. Furthermore, there was a noteworthy difference in damage assessment by the naked eye compared to the assessment by optical aids. Finally, significant differences in the ease of identifying damage between the different types of engine-driven endodontic instruments were found. However, this does not necessarily imply that one type of instrument is more prone to damage than the other.

\section{Acknowledgements}

The research was conducted within the Croatian Foundation for Research and Development of New Micro and Nanostructural Bioactive Materials in Dental Medicine BIODENTMED No. IP-2018-01-1719

\section{Conflict of interest}

The authors declare no conflict of interest.

Author's contribution: A.Š. - Devised the idea of research; organized and conducted the research, cowrote the manuscript; I.Š. - cowrote and proofread the manuscript, contributed substantially to discussion; V.B.R. - Participated in experimental design, proofread the manuscript; A.I.M. - Hypotesis, Participated in experimental design, proofread the manuscript; S.J.K. - Participated in experimental design, proofread the manuscript; I.M. - Participated in experimental design, proofread the manuscript, contributed substantially to discussion tička pomagala tek nedavno počela primjenjivati u stomatologiji (19). Zato su potrebna dodatna istraživanja.

\section{Zaključak}

Može se zaključiti da postoji značajna razlika između dobnih skupina u procjeni oštećenja instrumenta, $s$ tim da mlađi ispitivači mogu lakše uočiti oštećenje samo okom. Nadalje, uočena je različitost u procjeni oštećenja samo okom u odnosu prema optičkim pomagalima. Konačno, pronađene su značajne razlike u lakoći prepoznavanja oštećenja između različitih vrsta strojnih endodontskih instrumenata. No to nužno ne znači da je jedna vrsta instrumenta sklonija oštećenjima od druge.

\section{Zahvala}

Istraživanje je provedeno u sklopu Hrvatske zaklade za znanost - istraživačkog projekta Istraživanje i razvoj novih mikro i nanostrukturnih bioaktivnih materijala u dentalnoj medicini-BIODENTMED No. IP-2018-01-1719.

\section{Sukob interesa}

Autori izjavljuju da nisu bili u sukobu interesa.

Doprinos autora: A. Š. - osmislila ideju istraživanja, organizirala i provela istraživanje, napisala tekst; I. Š. - pisao i lektorirao rukopis, bitno je pridonio raspravi; V. B. R. - sudjelovala u eksperimentalnom dizajnu, lektorirala rukopis; A. I. M. - hipoteza, sudjelovala u eksperimentalnom dizajnu, lektorirala rukopis; S. J. K. - sudjelovala u eksperimentalnom dizajnu, lektorirala rukopis; I. M. - sudjelovala u eksperimentalnom dizajnu, lektorirala rukopis, znatno je pridonijela raspravi.

\section{Sažetak}

Cilj istraživanja: Odrediti preciznost vizualne procjene oštećenja rotirajućih i recipročnih endodontskih instrumenata vizualno i optičkim pomagalima. Materijal i postupci: Istraživanje su provela četiri ispitivača podijeljena $u$ dvije dobne skupine: 1 . skupina od 20 do 30 godina $-n=2$ i 2 . skupina od 40 do 50 godina $-n=2$. Vizualno su procijenili postoje li oštećenja rotirajućih ili recipročnih en dodontskih instrumenata samo okom i dvjema vrstama optičkih pomagala. Svaki ispitivač pregledao je ukupno 239 instrumenata različitih proizvođača. Svi su kalibrirali oko na novom instrumentu prije procjene oštećenja. Osjetljivost metode procjene obavljena je golim okom. Kada je instrument okom procijenjen kao oštećen, procjena je prekinuta te se instrument i dvjema drugim metodama procjene smatrao oštećenim. Rezultati: Pronađeno je oštećenje na 178 instrumenata. Osjetljivost procjene oštećenja okom iznosi 49,7 \%, za povećala $66,2 \%$, a za operacijski mikroskop 76,5\%. Trima metodama procjene oštećenja dobivene su značajne razlike u osjetljivosti $(p<0,05)$. Zaključak: Zaključeno je da postoji značajna razlika između dobnih skupina u procjeni oštećenja instrumenta. Također je uočeno da se razlikuje procjena oštećenja samo okom i optičkim pomagalima. Konačno, kad je riječ o lakoći prepoznavanja oštećenja, pronađene su značajne razlike između različitih strojnih endodontskih instrumenata. No ni jedna vrsta instrumenta nije bila sklonija oštećenjima od drugih.
Zaprimljen: 27. prosinca 2020. Prihvaćen: 18. ožujka 2021.

Adresa za dopisivanje Ivan Šalinović Sveučilište u Zagrebu Stomatološki fakultet Zavod za restaurativnu stomatologiju i endodonciju

Gundulićeva 5, Zagreb isalinovic@sfzg.hr

MeSH pojmovi: kvar opreme Ključne riječi: stomatološki instrumenti, procjena oštećenja, optička pomagala 


\section{References}

1. Perrin P, Neuhaus KW, Lussi A. The impact of loupes and microscopes on vision in endodontics. Int Endod J. 2014 May;47(5):4259.

2. Lopes DS, Pessoa MA, Aguiar CM. Assessment of the Centralization of Root Canal Preparation with Rotary Systems. Acta Stomatol Croat. 2016;50(3):242-250.

3. Aguiar CM, Sobrinho PB, Teles F, Câmara AC, Figueiredo JAP. Comparison of the centring ability of the ProTaperTM and ProTaper Universal ${ }^{\mathrm{TM}}$ rotary systems for preparing curved root canals. Aust Endod J. 2013 Apr;39(1):25-30.

4. Rubio J, Zarzosa JI, Pallarés AA. Comparative Study of Cyclic Fatigue of 10 Different Types of Endodontic Instruments: an in Vitro Study. Acta Stomatol Croat. 2019 Mar;53(1):28-36.

5. Li UM, Lee BS, Shih CT, Lan WH, Lin CP. Cyclic fatigue of endodontic nickel titanium rotary instruments: Static and dynamic tests. J Endod. 2002 Jun;28(6):448-51.

6. Khasnis S, Kar P, Kamal A, Patil J. Rotary science and its impact on instrument separation: A focused review. J Conserv Dent. Mar-Apr 2018;21(2):116-124.

7. Gencoglu N, Helvacioglu D. Comparison of the Different Techniques to Remove Fractured Endodontic Instruments from Root Canal Systems. J Conserv Dent. Mar-Apr 2018;21(2):116-124.

8. Eichenberger M, Perrin P, Neuhaus KW, Bringolf U, Lussi A. Visual acuity of dentists under simulated clinical conditions. Clin Oral Investig. 2013 Apr;17(3):725-9.

9. Urlic I, Verzak Ž, Vranic DN. Measuring the Influence of Galilean Loupe System on Near Visual Acuity of Dentists under Simulat- ed Clinical Conditions. Acta Stomatol Croat. 2016 Sep;50(3):235241.

10. Mohamud A, Erichsen J, Kessel L, Holm L, Larsen M. Presbyopia treatment. Ugeskr Laeger. 2019 Jan 28;181(5):V06180461.

11. James T, Gilmour ASM. Magnifying loupes in modern dental practice: an update. Dent Update. 2010 Nov;37(9):633-6.

12. MeSH Browser [database on the Internet]. [cited 2021 Feb 16] Available from: https://www.dentaleconomics.com/practice/article/16389879/the-benefits-of-high-magnification.

13. Sattapan B, Nervo GJ, Palamara JE, Messer HH. Defects in rotary nickel-titanium files after clinical use. J Endod. 2000 Mar;26(3):161-5.

14. Laustren L, Luebke N, Brantley W. Bending properties of nickel titanium rotary endodontic instruments . J Dent Res 1996; 75: 384.

15. Pruett JP, Clement DJ, Carnes DL. Cyclic fatigue testing of nickeltitanium endodontic instruments. J Endod. 1997 Feb;23(2):77-85.

16. Matheus Tibério César Uchôa. The fracture evaluation of NiT SMA endodontics files. Materials Research. 2007;10(4):395-98.

17. Rubio J, Zarzosa JI, Pallarés A. A Comparative Study of Shaping Ability of four Rotary Systems. Acta Stomatol Croat. 2015 Dec;49(4):285-93.

18. Low JF, Dom TNM, Baharin SA. Magnification in endodontics: A review of its application and acceptance among dental practitioners. Eur J Dent. Oct-Dec 2018;12(4):610-616.

19. Wajngarten D, Garcia PPNS. Effect of magnification devic es on dental students' visual acuity. PLoS One. 2019 Mar 27;14(3):e0212793. 